\title{
Conservation Strategy in Preserving The Local Image Existence of Wayang Topeng
}

\author{
Endang Wara Suprihatin ${ }^{\bowtie}$, Dyah Pratamawati \\ Department of Arts, Drama, Dance and Music, Faculty Languages and Arts, \\ Universitas Negeri Malang, Indonesia
}

Submitted: May 23, 2019. Revised: November 4, 2019. Accepted: December 28, 2019

\begin{abstract}
This research studies the strategic conservation efforts to preserve the local image of wayang topeng or mask puppet as a traditional art performance. Ten years into the 21st century shows a great effort from the artists who joined the Wayang Topeng Malang dance studio, Asmorobangun led by Tri Handaya (43), in preserving its existence. This research studies the strategy carried out in preserving the association's existence so it can continue, not only wayang topeng as traditional art performance but also as the professions of its artist. The efforts carried out shows an action which is systematic and modern. Therefore, the researcher is interested in exploring Tri Handaya's effort in preserving wayang topeng communities to be able to hold monthly regular performances, establishing cooperation with the government and private sector, and serving various training for general public. Research method used was qualitative approach of single instrumental case study, which is Sanggar Wayang Topeng Asmorobangun. Data was collected with the use of interview, observation, and documentation. Data verification to establish validity was using source and method triangulation. Research results show that there are three strategic aspects in preserving local image: (1) following the tradition patterns of its predecessors, (2) conducting training for young generations, (3) designing an extensive promotional media and building relationships with stakeholders.
\end{abstract}

Keywords: Strategy; Conservation; Wayang Topeng; Sanggar Asmorobangun

How to Cite: Suprihatin, E. W., \& Pratamawati, D. (2019). Conservation Strategy in Preserving The Local Image Existence of Wayang Topeng. Harmonia: Journal of Arts Research And Education, 19(2), 179-184.

\section{INTRODUCTION}

Wayang Topeng is a mask dance performance featuring a story or dance drama with masked actors (Murgiyanto, 1980). The traditional art of Wayang Topeng Malang in the 70s decade was once an icon of Malang city. This art has the characteristics of 1) carrying the Panji story, 2) all dancers (anak wayang) wear masks in accordance with the play being played, 3 ) the puppeteer is played by a man, serving as the sto- ryteller and conducting dialogue, because all anak wayang or characters do not have their own dialogue, except for Patrajaya who use half-face mask. (Pratamawati, 2016) found that the staging concept follows a predetermined structure and cannot be changed in accordance with the wishes of the puppeteer.

In the past, Wayang Topeng Malang grew and spread in several places in Malang regency, namely: Dampit, Precet, Wajak, Ngajum, Jatiguwi, Senggreng, Pu-

\footnotetext{
Corresponding author:

E-mail: e.w.suprihatin.fs@um.ac.id
} 
cangsanga, Jabung and Kedungmangga. But now only 4 groups of Wayang Topeng performers are still active and 3 of them are experiencing cutback and now 4 (four) Wayang Topeng groups remain (Hidajat, 2008).

The research subject is Wayang Topeng Malang Studio Organization in Kedungmonggo. Rationale behind conducting the research is that the studio has been consistently maintaining and developing Wayang Topeng Malang, both in its performance and also visual mask formed as souvenir products and properties for mask dance besides some accomplishments which have been achieved, and many domestic and foreign tourists who come to see the show, learn to dance or learn to sculpt or to paint a mask which make this studio popular. In addition, Asmorobangun Studio has a unique character in the presentation of the dance drama, as well as the conservation efforts are undertaken.

Research by Pratamawati (2017), found that for certain interests such as Bersih desa or other celebrations, Wayang Topeng performance is still held conventionally all night long, so that the audience has to prepare to enjoy the whole night show. However, for the sake of tourism, a short presentation is made with a duration of 1-2 hours. As for scientific development related to the school curriculum, several character dances, namely, Grebeg Sabrang, Gunungsari, Sekarsari, and Patih are packaged in a short duration of 4-6 minutes as Rahayuningtyas Wida mentioned in her thesis (Rahayuningtyas, 2012).

The term conservation in this research means an ongoing effort to maintain, develop, manage, and protect the Sanggar Asmorobangun organization continuously to avoid extinction and preserve traditions. Generally, Suwandono (Sedyawati, 1984) states that: some strategies implemented to maintain the existence of traditional art may be directed to the process of traditional elements which are given a new touch according to the level of its development period without reducing or eliminating the values of tradition and or dissemination so that it can be enjoyed by the wider community environment. The conservation strategy in maintaining the local image of the Wayang Topeng is a traditional performing art is carried out over the last ten years and shows that there is a strong effort from the artists who are members of the Asmorobangun dance group led by Tri Handaya (43 years).

The flow of globalization which is considerably fast becoming a threat to the existence of local culture and local traditional arts can inevitably experience the erosion of cultural values because it is a risk of Indonesia's position as part of the global community. Globalization is a necessity that cannot be prevented, but its effects that can kill local culture should not be left alone. Local culture needs to strengthen its resilience in the face of globalization of foreign cultures. Powerlessness in dealing with the change of culture is tantamount to letting go of the local image. Globalization must be addressed wisely as a positive result of modernization that pushes people forward. However, local culture actors must not be careless and complacent because the era of openness and freedom also has a negative influence that will damage the nation's culture. Conservation of traditional performing arts does require hard work cooperatively between artists, the community, the government, and the potential of the art itself.

Conservation of art performance organizations generally includes preservation and protection. In the context of preservation, some aspects that can be improved are maintenance, rescue, research, excavation, and recording. While in relation to protection, various ways can be done, such as development, and dissemination.

The development being discussed in this study is the management of the dance's main and supported elements by giving a new touch (approach) adjusted to the interests and tastes of the present society without removing the main content of the traditional elements. Development can also be interpreted as dissemination, 
the intention which makes the art enjoyable and able to be studied by the wider community. This is in line with Suwandono's statement (1984). Making it into the content of local curriculum materials can also be included in the dissemination category; doing a creation so that it looks different from the original but with the characteristics that can be categorized as dissemination including creating it as a cultural tourism show.

Conservation strategies carried out in the Studio include maintenance, guidance, management, and protection. Maintenance is carried out by maintaining the sustainability of the studio activities, both in the field of performance and also arts (making the Malang Mask). The aspect of development is carried out by the government and related institution, in this case is Universitas Negeri Malang, by frequently involving the Studio in various events and also incorporating Malang Mask material as a compulsory local content that must be studied by students of Dance and Music Education Study Program in all study program concentrations (dance, music, drama). The management of the Studio is under one family management, which is currently led by Handoyo as the heir to the descendants of Karimun. In keeping the Studio's presence, protected from global trend that lead to the creation of art, the way to do this is to routinely organize various dance training and mask-making training, both on the basis of established programs and also at the request of stakeholders.

\section{METHOD}

The research method used is qualitative with a holistic single-case study (Yin, 1996). The reasons for choosing this research method are: 1) the subject under study is an important activity; 2) it is unique; 3 ) it is the disclosure of an event carried out by an organized group of people (Yin, 1996). This study intends to track phenomenal events and cannot be manipulated because the data obtained are from real events and not experiments. Data collecti- on techniques in this study used multiple sources (Yin, 1996) which is: 1) interview, 2) observation, and 3) documentation study.

Researchers conducted in-depth interviews with informants who are considered to be able to provide answers to what and how Asmorobangun Studio Organization carried out the efforts in conservation strategies. The selection of informants is carried out using snowball sampling techniques. In this case, one of the key informants was Tri Handoyo as the heir of the Kedungmonggo Wayang Topeng Studio which has consistently managed and developed the studio until now. Other interviewees are Wida Rahayuningtyas (lecturer and also the head of the art and design department) as well as a researcher who consistently developed research types in the development of Malang Mask-based learning media, Roby Hidajat (head of the master degree teacher study program and lecturer) as a qualitative researcher of Malang Mask art and also researcher, myself, as an active actor who every year (since 2010 till now) cooperates in carrying out various events based on Malang Mask and is consistent with the research of the management of the tradition Studio.

The research procedures conducted in this study are: 1) conducting interviews with key informants or people in the form of structured or unstructured questions carried out in-depth; 2) observing an active role; 3) conducting documentation study from several previous research results related to Wayang Topeng Malang. Data verification is done through source triangulation and technical triangulation, while data analysis uses a braided analysis model where the data reduction component, data presentation, and conclusion are verified and carried out continuously (Sutopo, 2006).

\section{RESULT AND DISCUSSION}

Performing arts in Indonesia are very diverse and each has its own uniqueness in accordance with the place and charac- 
teristics of local communities. Therefore, directly or indirectly it will affect the form and genre of the performance art itself. In addition, the existence of colleges with arts majors are spread in several regions of Indonesia also made a major contribution to the strengthening of the institutionalization of traditional performance arts, academically it is not only in the undergraduate level but also up to the doctoral level.

The fact mentioned is a factor that should be able to make the traditional performing arts still exist in Indonesia. However, in reality, we encounter some extinct traditional performing arts due to several factors, for example, the change from a closed society to a more open society, from homogeneous values to pluralism, the existence of globalization and international means of transportation that removes cultural boundaries. Likewise, with the existence of a more sophisticated communication technology system, the community is finally open to many alternative entertainment choices that are felt to be more in line with the views and tastes of the community.

This has caused more traditional performance arts to be excluded, and one of the traditional performance arts in Malang is Wayang Topeng Malang. Initially, almost every sub-district in the Malang area had a Wayang Topeng studio, but now only four are active. One of them is the Asmorobangun Studio located in Kedungmangga Hamlet, Malang Regency. Formerly led by (now deceased) Mr. Karimun, but now led by his grandson named Tri Handoyo. Tri Handoyo is a young figure who is very keen to preserve the Wayang Topeng existence in his village, even though academically he is a graduate in communication degree.

Under his leadership, various things were done for the development of the show, the development of the mask product, and other things. All the efforts were carried out as a conservation strategy in maintaining the existence of local images. From the results of the research, several things related to the strategy carried out by the Sanggar Asmorobangun organization in maintaining its existence are 1) following the traditional pattern of its predecessors; 2) conducting training for young people; 3) designing promotional media and extending relationships with stakeholders.

\section{Following the Tradition Pattern of Its Predecessors}

In connection with efforts to preserve traditional art, Sanggar Asmorobangun still maintains the presentations with the conventional concept and supporting performances namely:

The stage concept is still the same as Malang style performances or Malang style traditions where the initial presentation always starts with the opening music or introduction, commonly called as Giro, as stated by (Supriyanto \& Pramono, 1997), that the structure of the wayang topeng presentation follows a certain pattern. After the Giro, it proceeds to the Opening Dance, and continued with the core presentation that is divided into several scenes (jejer). Structurally, the order of presentation is also still following the traditional pattern. The duration of presentation time for an act takes an average of 9 hours, from 20.00 to 05.00 (morning). It's just that the presentation of the whole play is not always done every time, but only at certain times, for example when being asked to play at a celebration and other events.

Supporters namely the role of the puppeteer (dalang), the role of puppets (anak wayang), the role of panjak (gamelan player), the role of punokawan, is still the same as when it was led by the founding father Mr. Karimun. The role of the puppeteer in the Wayang Topeng performance in the studio is still the same which is as the narrator and director whose task is to attract the audience's attention through his duties in conveying janturan, pocapan, and ontowecono as the description stated by (Supriyanto \& Pramono, 1997)

The venue is in the form of proscenium, but sometimes also in the open field, usually when a village celebrates annual 
ceremony, like, bersih desa, or a birthday of the studio is held once a year, then the performance is held in two places, namely in the Studio and in the punden (tomb). The Wayang Topeng show was held in Studio, while in the punden only a few snippets were shown, namely the Ragil Kuning dance, Gunungsari, Demang, and Patrajaya. After dancing, the figures were paraded around the hamlet. This is in line with what was conveyed by Sal Murgiyanto and A.M. Munardi that such an act is believed to make the predecessors or pepunden of the village, who was also a dancer, happy and well-pleased so that he will maintain the safety and prosperity of the village and all its citizens (Murgiyanto, 1980).

Accompaniment music, in the form of a set of musical instruments with Laras Pelog or commonly referred to as the Laras Sendaren. Also, the structure of the scene and the gending it plays still follows the old pattern, starting from the Giro and so on. To maintain the quality of gamelan playing skills, routine training is carried out every Friday and Sunday from 20.00 to 22.00 .

\section{Conducting Training for Young People}

The younger generation needs creative space because they have very high talent and desire to represent themselves, but the space to grow is often not comparable to what is called human resources, meaning that the required places to perform the arts are less than the human resources. The young generation should not only enjoy the show but also know the process of the performance arts.

Handoyo as the successor and manager of the Studio conducts dance training activities for sons and daughters who want to be able to do Mask dance. The training activities are carried out routinely every Sunday starting at 9:00 to 12.00 , and participation is free of charge. When a performance activity is near, the training frequency is increased. The training was given not only to improve skills but also as an effort to equip human resources in the team to make maximum contributions in accordance with their position in the team. What was done, is in line with the recommendations of Sunyoto Danang and Susanti Eka Fathonah (Sunyoto, 2015).

The training of musicians and dancers were coordinated by Handaya himself as the leader of the Studio, assisted by his wife without involving outsiders. The applied communication network is in the form of a star as a model of the communication network delivered by Gito Sudarmo Indriyo as shown below (Indriyo, 1997).

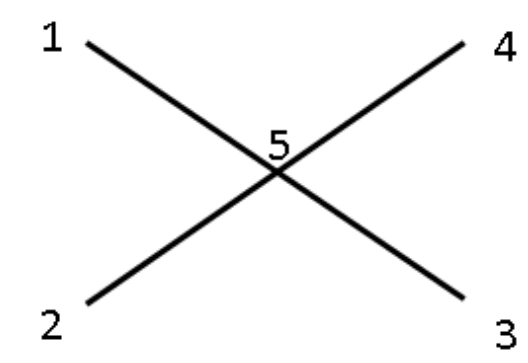

Figure 1. Communication Network Chart. Source: Gitosudarmo \& Sudita (1997)

This is done so that activities are more centralized, effective, and efficient and the enrichment or character style of the presentation form maintained its authenticity, and if there are problems arise, it is more quickly overcome. The person in the middle functions as a leader, who collects information from group members, determines the solution while also organizing it.

\section{Designing Promotional Media and Ex- tending Relationships with Stakehold- ers.}

Through various promotional media used by Handaya as Studio leader, the area of the Studio distribution not only reach the whole country but also penetrated overseas. The communication facilities used by the studios to introduce and market their organizations are by utilizing social networks in the form of Facebook, Email, WhatsApp, Websites, and also partners and distribution of business cards as a result of research conducted by Pratamawati Dyah (Pratamawati, 2017).

Whereas the development of other 
relationships undertaken was to become a lecturer in the Dance and Music Education Study Program, State University of Malang, as a guest lecturer (previously called Extraordinary Lecturer/Extraordinary Lecturer). Handaya's involvement is not only in learning but also in implementing various events conducted by Universitas Malang. Also, together, with Universitas Malang lecturers to package a variety of character dances into a short duration performing art in the hope that the dance will be easier to be taught at school. The dance produced in collaboration with a researcher named Rahayuningtyas has become a local content for extracurricular and even curricular activities in several schools in Malang Raya (Rahayuningtyas, 2012)

\section{CONCLUSION}

The conservation strategy undertaken by Sanggar Asmorobangun in maintaining the existence of local images is through 1) following the traditional pattern of its predecessors, namely by maintaining the presentation of the show with the conventional concept and supporting performances starting from the form of performance, staging, and accompaniment. 2) conducting training for young people by holding training and regenerating the children members to be involved and active in traditional arts. 3) designing promotional media and extending relationships with stakeholders, in this case, it is very necessary for Asmorobangun Studio to make the studio itself becomes more active in promoting the studio.

\section{REFERENCES}

Hidajat, R. (2008). Wayang Topeng Malang: Struktur dan Simbolik Seni Pertunjukan Tradisional di Malang Jawa Timur. Malang: Gantar Gumelar.

Indriyo, G. (1997). Perilaku Organisasi. Yogyakarta: BPFE.

Murgiyanto, S. (1980). Topeng Malang: Pertunjukan Dramatari Tradisional di Daerah Kabupaten Malang. Jakarta: Proyek Sasana Budaya. Direktorat Jenderal Kebudayaan Departemen Pendidikan dan Kebudayaan.

Pratamawati, D. (2016). Fungsi Penampilan Wayang Topeng Asmarabangun Dalam Perubahan Sistem Sosial Masyarakat Desa Kedungmangga.

Pratamawati, D. (2017). Strategi Promosi Sanggar Wayang Topeng Asmara Bangun Dusun Kedungmonggo Untuk Pentas Internasional.

Rahayuningtyas, W. (2012). Pengembangan Bahan Ajar Matakuliah Vokasi Tari Malang. Malang: Universitas Negeri Malang.

Sedyawati, E. (1984). Tari: Pembinaan Dan Pengembangan Tari Tradisi (Bunga Rampai oleh Suwandono). Jakarta Pusat: PT Dunia Pustaka Jaya.

Sutopo, H. B. (2006). Metode Penelitian Kualitatif. Surakarta: Universitas Sebelas Maret.

Sunyoto, D. (2015). Manajemen Pemasaran Jasa: merencanakan, Mengelola dan Membidik Pasar Jasa. Yogyakarta: CAPS (Center Of Academic Publishing Service).

Supriyanto, H. \& Pramono, M. S. A. (1997). Drama tari: wayang topeng Malang. Malang: Padepokan Seni Mangun Dharma Tumpang.

Yin. (1996). Studi Kasus (Desain dan Metode). Jakarta: PT Raja Grafindo Persada. 